AGRO EKONOMI, Vol 31, Issue 1, June 2020, Page.16-29

DOI : http://doi.org/10.22146/ae.52815

ISSN 0215-8787 (print), ISSN 2541-1616 (online)

Available at https://jurnal.ugm.ac.id/jae/

\title{
FARMERS' WILLINGNESS TO CONTINUE CORPORATE FARMING PROGRAMS IN JETIS SUBDISTRICT, BANTUL REGENCY, YOGYAKARTA
}

\author{
Putri Perdana ${ }^{1 *}$, Jamhari ${ }^{2}$, Irham ${ }^{3}$ \\ ${ }^{1,2,3}$ Department of Agricultural Socio-Economics, Faculty of Agriculture, Universitas \\ Gadjah Mada, Yogyakarta, 55281, Indonesia \\ *Corresponding author: putri.perdana@mail.ugm.ac.id
}

Submitted: 29 April 2020; Revised: 11 February 2020; Accepted: 6 April 2020

\begin{abstract}
Corporate Farming (CF) program is one of the innovations in the field of agricultural institution in realizing more effective and efficient farming through consolidation of paddy field. This program was carried out in Trimulyo Village, Jetis Sub-district, Bantul Regency with Barokah Farmer Group as a pilot project. This study aims to (1) determine farmers' willingness to continue the CF program and (2) determine the factors that affect farmers' willingness to continue the CF program. The study was conducted by surveying 52 smallholder farmers, members of Barokah Farmer Group who joined the CF program. The data were analyzed by using proportion test and Ordinary Least Square (OLS) model. The results show that the farmers' willingness to continue the CF program was $66.54 \%$. Attitudes towards private property rights, interaction among the members of farmer group, family member support, age and education were the factors affecting farmers' willingness to continue the CF programs. Farmers' willingness to continue the $\mathrm{CF}$ program was categorized as high. Socialization and a more intense mentoring on the objectives of the CF program can increase farmers' willingness to continue the program.
\end{abstract}

Keywords: Barokah Farmer Group; Consolidation; Corporate farming; Paddy fields; Willingness to continue

How to cite: Perdana, P, Jamhari, \& Irham. 2020. Farmers' Willingness to Continue Corporate Farming programs in Jetis Subdistrict, Bantul Regency, Yogyakarta. Agro Ekonomi, 31(1), 16-29

\section{INTRODUCTION}

Corporate Farming (CF) is an economic development program by Bank Indonesia in collaboration with the Faculty of Agriculture UGM Yogyakarta, UPTD BPTP DIY and BPP Jetis as the solution of the problems faced by Barokah Farmer Group. The aim was to increase rice productivity and achieve technical efficiency. The CF program also aims to reduce the use of chemical inputs in rice farming activities. Rice farming carried out by the members of Barokah Farmer Group in Jetis Subdistrict has experienced a decline in rice productivity. Difficulty of the planting workforce in this area also impeded farming activities. The CF program was run by a three-year contract period, from 2016 to 2019 . The CF program was 
run through the incorporation of paddy field to be managed together under one management.

Paddy field consolidation that was conducted as a form of the CF implementation in Jetis Subdistrict is in the form of merging paddy fields owned by 4 to 6 farmers who were the members of Barokah Farmer Group into one block. It is done by eliminating paddy fields' borders (galengan) which separated rice field ownership among the members of the farmer group. Block leader was appointed as the coordinator and the contact person among CF caretaker and its associates (stakeholders) with the members of the farmer group. The block leader also served as the distributor of fertilizer provided through this program. Funding from land management to postharvest on the land was guaranteed by the CF management who had received funding from the stakeholders.

Swain et al. (2012) stated that CF could stabilize Inflows and outflows thus reaching economies of scale. Bose (2013)Contract and Corporate Farming," by Amit Kumar Bose, published in the Journal of Land and Rural Studies (Volume 1, Issue 1 also stated that large-scale $\mathrm{CFs}$ were more efficient and lead to allocation efficiency, encourage investment from the private sector and generate higher output and income. Kasijadi et al. (2003) in their research explained that $\mathrm{CF}$ generated economic and social benefits. The economic benefits consisted of production costs reduction, production efficiency and member's income improvement. The social benefits could be in the form of education, cooperation among members and a more suitable atmosphere of rural development.

Currently, the program implementation contract with Barokah Farmer Group has been ended. However, the implementation of the CF program was deemed not optimal yet by farmers. It is because during the implementation of the CF program, rice productivity decreased even though the purpose of the program implementation was the increase in rice productivity of the Barokah Farmer Group. This study aims to determine farmers' willingness to continue the CF program and the factors affecting farmers' willingness to continue the CF program. The essential variables include attitudes towards private ownership, interaction among the members of farmer group, support of family members, age, education and adopted CF land area from Allahyari et al. (2018); Armstrong \& Stedman (2012); Hiironen \& Riekkinen (2016); Jan \& Akram (2018); Perwitasari et al. (2018); Sardianou \& Genoudi (2013) and Susanti et al. (2016). Trust to stakeholders variable adopted from Fischer \& Wollni 
(2018). The novelty of this research is that the measurement of farmers' willingness to continue the CF program has never been done before. This study is important because having farmers' willingness to continue the CF program will open more possibility that this program has been success and can continue even though the cooperation contract with stakeholders has been completed.

\section{METHODS}

The research location was determined by purposive sampling based on the availability of CF institusional facilitation by Bank Indonesia (BI). The research location was in Trimulyo Village, Jetis Subdistrict, Bantul Regency, Special Region of Yogyakarta. The respondents consisted of 52 smallholder farmers who were selected by census.
The respondents were the members of Barokah Farmer Group applying CF program since 2016 until now in the paddy field pilot namely Bulak Ancak Block. The research was conducted on August until September 2019.

Farmers' willingness to continue the CF program was measured through social and attitude dimension. The social dimension consists of statements of interaction variable between farmers' group members and relationships with family members. The attitude dimension consists of the attitude statement variable towards private ownership and trust. Those willingness construct indicators were adopted from Perwitasari etal. (2018) research (Table 1). The validity and reliability of all the variables in this study were tested. And then, the responses to the answers from the statement items in the form

Table 1. Construct of Indicators on Willingness to Continue the CF Program

\begin{tabular}{|c|c|c|}
\hline $\begin{array}{l}\text { Attitudinal Dimension } \\
\text { Indicator }\end{array}$ & Definition & $\begin{array}{l}\text { Response } \\
\text { Statement }\end{array}$ \\
\hline $\begin{array}{l}\text { Attitudes towards private } \\
\text { ownership }\end{array}$ & $\begin{array}{l}\text { Farmer's response to the use of privately } \\
\text { owned land to support the CF program }\end{array}$ & $1-5$ \\
\hline Trust to stakeholders & $\begin{array}{l}\text { Willingness to rely and depend on others } \\
\text { and have confidence on that person }\end{array}$ & $1-5$ \\
\hline \multicolumn{3}{|l|}{ Social Dimension Indicator } \\
\hline $\begin{array}{l}\text { Interaction among the members } \\
\text { of farmer group }\end{array}$ & $\begin{array}{l}\text { Cooperation in the farming among } \\
\text { members }\end{array}$ & $1-5$ \\
\hline $\begin{array}{l}\text { Relationship with family } \\
\text { members }\end{array}$ & $\begin{array}{l}\text { Support and help from family members on } \\
\text { rice farming }\end{array}$ & $1-5$ \\
\hline
\end{tabular}

Source: Adopted from Perwitasari et al., 2018

Description:

1 - 5 = strongly disagree - strongly agree 
of ordinal data were transformed into interval data by means of the Summed Rating Method.

\section{Method of Analysis}

To see the willingness of the members of Barokah Farmer Group in continuing CF program, a proportion test was carried out using the following formula (Simanjuntak et al., 2016):

Description:

$$
\mathrm{P}=\frac{X}{Y} \times 100 \%
$$
$\mathrm{P}=$ Proportion of farmers' level of willingness

$\mathrm{X}=$ The number of farmers who are willing to accept and continue the CF program (inhabitant)

$Y=$ Total Farmer Respondents (inhabitant)

These scores were interpreted by the following criteria (Anwar, 2015):

$\begin{array}{ll}\text { Very low } & =0-20 \% \\ \text { Low } & =21-40 \% \\ \text { High enough } & =41-60 \% \\ \text { High } & =61-80 \% \\ \text { Very high } & =81-100 \%\end{array}$

The factors of farmers' willingness to continue the CF program were analyzed by using Ordinary Least Square (OLS). The model used based on Perwitasari et al., (2018) is as follows:
$\mathrm{Y}=\beta_{0}+\beta_{1} \mathrm{X}_{1}+\beta_{2} \mathrm{X}_{2}+\beta_{3} \mathrm{X}_{3}+\beta_{4} \mathrm{X}_{4}+\beta_{5} \mathrm{X}_{5}+$ $\beta_{6} X_{6}+\beta_{7} X_{7}+\beta_{8} X_{8}+\beta_{9} X_{9}+e$

Description:

$\mathrm{Y}=$ Willingness to continue the $\mathrm{CF}$ Program (scale)

$\beta_{0}=$ constant

$\beta_{1}-\beta_{2}=$ regression coefficient

$\mathrm{X}_{1}=$ attitudes towards private ownership (scale)

$\mathrm{X}_{2}=$ interaction among the members of farmer group (scale)

$\mathrm{X}_{3}=$ support of family members (scale)

$\mathrm{X}_{4}=$ trust to stakeholders (scale)

$\mathrm{X}_{5}=$ farming performance with $\mathrm{CF}$ program (tonnes/hectare)

$\mathrm{X}_{6}=$ age (years old)

$X_{7}=$ number of family dependents (inhibitant)

$\mathrm{X}_{8}=$ education (years)

$\mathrm{X}_{9}=\mathrm{CF}$ land area (hectare)

$\mathrm{e}=$ error

In this study, the dependent variable (farmers' willingness to continue the CF Program) used was response answers from 12 statement items. Therefore, the data obtained were ordinal which should be transformed into interval data employing Summed Rating Method. The formula used in Summed Rating Method according to Azwar (1999) is as follows: pk-middle $=1 / 2 p+p k b$

Description:

pk-middle $=$ midpoint of the cumulative proportion 
$\mathrm{p}=$ proportion in the category concerned $\mathrm{pkb}=$ cumulative proportion in the categories on the left.

\section{RESULTS AND DISCUSSION}

Validity test of all statements in this study was carried out using Pearson correlation test, results show that value of $r$ count of all the statements were greater than value of $r$ table. It means that all statements used in this study were valid. Reliability test in this study used Cronbach alpha, results show that value of those variables was more than 0.6 , meaning it is reliable.

\section{Characteristics of farm households}

The majority of Barokah Farmer Group's members were in the productive age category or at the age of 15 to 64 years accounted for 58 percent from the whole respondents. The average age of farmers was 61 years old. Farmers who were the members of Barokah Farmer Group had an average of 32 years of farming experience. The majority of the members of Barokah Farmer Group had primary school education, reaching up to 44.23 percent. There were 3.85 percent of farmers who had undergraduate degree. This shows that most of the members of Barokah Farmer Group receive formal education.

The majority of farmers who belong to the Barokah Farmer Group had a family members of 2 to 3 people (50\%). They contributed in the process of farm management so that labor needs can be met from the family. As much as 67.31 percent of farmers whose paddy fields were used as a pilot project for the implementation of the CF program had an area of 0.015 to 0.07 ha with an average paddy area of 0.04 ha. The majority of rice productivity was between 0.31 to 4.70 tons per ha (82.69\%) with an average productivity of 2.39 tons per ha. Paddy land with the largest CF implementation was 0.22 ha with the biggest rice productivity of 13.47 tons per ha.

\section{Willingness to continue (WTC)}

Farmers' willingness to continue the CF program was 66.54 percent, categorized as a high scored criterion. With such high level of farmers' willingness, it is expected that farmers will become more cooperative and willing to continue this CF program. In implementing the CF program, Barokah Farmer Group receives operational funding assistance from Bank Indonesia. The funds were used for the operations of CF program, improved irrigation, purchase of inputs and agricultural machinery which include rice seeding machine, transplanter and tractors, and the construction of a farmhouse on area. The agricultural machinery was 
used together to cultivate the land, so it makses farmers be easier to work on the rice cultivation process and saves labor and time.

The farmers' willingness to continue CF program was measured using 12 statement items (Table 2) with the highest score was the farmers' willingness to continue to make rice cultivation activities together (74.62\%). Larger paddy field took longer time for rice cultivation compared to the one usually done by individual farmer. Therefore rice cultivation activities were done together along with the use of seed planting machines, tractors and planting machines to shorten the time and cost of cultivation.

The statement item with the lowest score was the farmers' willingness to continue to carry out marketing activities together $(53.46 \%)$ because farmers perceived that marketing the outputs together was less flexible. By marketing the outputs together, farmers had stigma that they could not withdraw their funds directly. Farmers assumed this because when their outputs marketed together or collectively they have to wait for the output from all members were collected and then sell that in the cooperative. It takes a long time and basically the farmers carry out rice farming activities to meet the needs of rice so they do not need to buy. They prefer to keep the rice
Table 2. Statement of Farmers' Willingness to Continue the CF Program

\begin{tabular}{|c|c|}
\hline Items & $\begin{array}{l}\text { Percentage } \\
(\%)\end{array}$ \\
\hline $\begin{array}{l}\text { Rice cultivation done } \\
\text { together }\end{array}$ & 74.62 \\
\hline $\begin{array}{l}\text { Rice planting done } \\
\text { together }\end{array}$ & 73.85 \\
\hline $\begin{array}{l}\text { Paddy field management } \\
\text { done together }\end{array}$ & 72.69 \\
\hline Fertilizing done together & 72.69 \\
\hline Seeding done together & 71.54 \\
\hline Pest control done together & 71.15 \\
\hline $\begin{array}{l}\text { Paddy fields } \\
\text { incorporations done } \\
\text { together }\end{array}$ & 68.46 \\
\hline $\begin{array}{l}\text { Machinery cultivation } \\
\text { done together }\end{array}$ & 66.15 \\
\hline $\begin{array}{l}\text { Using Services of Farming } \\
\text { Tools and Machinery } \\
\text { (UPJA) done together }\end{array}$ & 66.15 \\
\hline $\begin{array}{l}\text { Not using rice field } \\
\text { borders }\end{array}$ & 65.77 \\
\hline $\begin{array}{l}\text { Market farm output in } \\
\text { a Cooperatives done } \\
\text { together }\end{array}$ & 56.54 \\
\hline Marketings done together & 53.46 \\
\hline $\begin{array}{l}\text { Farmers' Willingness to } \\
\text { Continue the CF Program }\end{array}$ & 66.54 \\
\hline
\end{tabular}

Source: Primary Data Analysis, 2019

for their own consumption. But at the moment they do not have the money to meet their needs, they sell it to a neighbor or grocer around their house. Barokah Farmer Group members prefer selling their own harvest rather than selling to collectors or loggers because not all harvests are sold.

There were several reasons underlying the farmers' decisions on farmers' willing to continue CF program. 
The highest reason is following the group's decision (32.26\%). If the group - in this case is the CF management and several members of Barokah Farmer Group - agreed to continue the program, then other members would follow. The effort of group management as $\mathrm{CF}$ management in improving farmers' willingness to continue the CF program was facilitated by guidance and assist at the beginning of each planting season and at harvest time. They also assisted farmers in the operation of the machines used and always provided rice seedlings to be utilized by farmers. They conducted training in making organic pesticides and provided them in paddy fields for direct use by farmers. Basically, they wanted to facilitate the farmers in the process of implementation of the CF program. In fact, the CF management had a significant influence on the farmers' willingness to continue the program because they were used as a role model in implementing the CF program. Another reason for the farmers who were willing to continue the CF program was to maintain harmony and togetherness among the members of the farmer group (29.03\%). Barokah Farmer Group members preferred all the activities to be carried out together. This is considered to be able to improve connection among members because as much as 62.79 percent of the members of Barokah Farmer Group chose farming for only a side job so that they wantede to work jointly.

This program is considered to provide a lot of new knowledge and techniques related to rice cultivation using machines. For example, farmers could learn how to breed using a seedling machine and operate transplanters also tractors accompanied by experts and CF managements. Farmers also learned how to apply jajar legowo planting system (2:1). CF implementation begin with consolidating the rice fields belonging to each member of the farmer so that land could be managed technically using a tractor so its effective and efficient because it did not require much time and labor involved. Using the transplanter during planting rice also reduces labor costs and number of planting workers. The cost of using a machine is cheaper than the cost of labor. The cost for labor in once planting usually is between IDR 100,000 to IDR 300,000 while the cost of leasing a transplanter is only IDR 2,700 per $10 \mathrm{~m}^{2}$. The use of these machines can save time and costs incurred by farmers members of the Barokah Farmer Group. The increase of rice productivity in the Barokah Farmer Group occured when farming with the CF program was fully organic. Currently the rice farming activities carried out was conversion from non organic to organic farming thus input costs can also be reduced and it is more efficient. 
Factors affecting farmers' willingness to continue the CF program

The factors affecting farmers' willingness to continue the CF program in this study were analyzed using OLS model that has been qualified in classical assumption test of normality test, multicollinearity and heteroscedasticity test. Jarque-Bera Probability value obtained from normality test was 0.202 $(>0.05)$ meaning that the model is normally distributed. Centered VIF value of the nine independent variables was 1.2 to $2.9(\mathrm{VIF}<10)$, indicating that this model is free of multicollinearity problem. Heteroscedasticity testing in this study used test Glejser. The results showed that nine variables had a significant value between 0.08 to 0.92 (sig.>0.05), it means that model is free of heteroscedasticity problem.

The significance value of $\mathrm{F}$ (Table 3) was 0.00 meaning that concurrently attitudes towards private ownership, interaction among the members of the farmer group, support from family members, trust to stakeholders, farming performance with CF programs, age, number of dependent family members, education and CF land areas

Table 3. Factors Affecting Farmers' Willingness to Continue CF Programs

\begin{tabular}{|c|c|c|c|c|}
\hline Variable & Expected Sign & Coefficient & t-Statistic & Prob. \\
\hline Attitudes towards private ownership & + & $0.05^{*}$ & 1.91 & 0.06 \\
\hline $\begin{array}{l}\text { Interaction among the members of } \\
\text { farmer group }\end{array}$ & + & $0.03^{*}$ & 1.84 & 0.07 \\
\hline Support from family members & + & $0.06^{*}$ & 1.97 & 0.06 \\
\hline Trust to stakeholders & + & $0.02^{\text {ns }}$ & 1.34 & 0.19 \\
\hline Farming performance with CF program & + & $-0.03^{\mathrm{ns}}$ & -0.80 & 0.43 \\
\hline Age & - & $0.02 *$ & 1.90 & 0.06 \\
\hline Number of dependant family members & + & $-0.07^{\mathrm{ns}}$ & -0.80 & 0.43 \\
\hline Education & + & $0.07^{* * *}$ & 2.72 & 0.01 \\
\hline CF land area & + & $-1.70^{\mathrm{ns}}$ & -0.73 & 0.47 \\
\hline $\mathrm{C}$ & $+/-$ & -3.51 & -4.32 & 0.00 \\
\hline R-squared & & 0.72 & & \\
\hline Adjusted R-squared & & 0.67 & & \\
\hline S.E. of regression & & 0.58 & & \\
\hline Sum squared resid & & 14.04 & & \\
\hline Log likelihood & & -39.74 & & \\
\hline F-statistic & & 12.28 & & \\
\hline Prob(F-statistic) & & 0.00 & & \\
\hline
\end{tabular}

Source: Primary Data Analysis, 2019

Description:

*** $\quad$ : significant at $1 \%$ error rate (t-table: 2.41847 )

* $\quad$ : significant at $10 \%$ error rate (t-table: 1.68195$)$

ns : not significant 
are influential tangible to farmers' willingness to continue the CF program. The adjusted R-squared value of 0.67 indicates that 67 percent of the variable willingness to continue the CF program can be explained by those variables while the remaining 33 percent is explained by other variables not contained in the model.

Attitude towards private ownership had a positive and significant effect. Feelings of belonging to the resources owned by members of Barokah Farmer Group differ. The more members of the Barokah Farmer Group feel they have the resources, the more careful they will be in managing their resources. The CF program gradually changed rice farming to semi organic because of the reduction in the use of chemical inputs. It affected farmers' willingness to continue the CF program because at the moment farmers in the Barokah Farmer Group started to be aware of a sustainable agricultural environment. The theory of psychological ownership (PO), which can be described as a condition where individuals feel that they have an object and become part of the object so that a strong psychological and behavioral effect arises will be a foundation of farmers' attitude towards private ownership. Psychological and behavioral effects that are formed can be explained as a possessive attitude towards the object that they have (Pierce et al., 2001 \& Pickford et al., 2016). When they thought they had more resources, they would unconsciously form an attitude to protect and try their best to improve the resources that they had. CF program can provide various benefits for farmers (Wahyuni \& Pranadji, 2015; Musthofa \& Kurnia, 2018)\{“id":"ITEM-5",'itemData” :\{“DOI”:"10.1177/2321024913483037 ",'ISSN":"2321-0249","'abstract":"'It has been brought to the publisher's attention that the article "Issues of Landlessness, Contract and Corporate Farming," by Amit Kumar Bose, published in the Journal of Land and Rural Studies (Volume 1, Issue 1. The existence of these benefits affects the willingness of farmers to continue the program. The more benefits they acquire from this program, the more willing they are to continue the program.

Support from family members had a positive effect on farmers' willingness to continue the CF program. In its application, CF program activities were carried out by the farmers together with the groups that had been established previously. If a group member was unable to attend the joint activity, the farmer would do it individually or together with their family members. Family members participated in the implementation of the CF program would increase the farmers' motivation. When 
family members also participated and supported, farmers felt more motivated to follow all the procedures of the $\mathrm{CF}$ program implementation.

Interaction among the members of the farmers' group had a positive and significant effect on farmers' willingness to continue the CF program. There were two interactions occured in the Barokah Farmer Group. The interaction among members of the farmers' group took place during meetings, rice cultivation activities in the field, irrigation activities and other activities that discussed technical matters in the field and the difficulties faced by the group. More frequent of interactions could minimize the difficulties faced by the farmers and affects the willingness of the farmers to continue the CF program. Besides, the interaction among the members of farmer group with the CF management through input regarding the application of CF in farming activities occured. Since the CF management had a high level of educational background (undergraduate) so that a given input would be listened by members. When the CF managements were willing to continue the program, other members of the farmer group were also willing to continue the program. This is related to the conformity theory, i.e. a type of social influence in which individuals will change their attitude and behavior to conform to the existing social norms. One of factors that affect conformity is group cohesiveness. The more cohesive the group is, the stronger the influence in forming the thought patterns and behavior of group members. (Brown, 2006).

Age had a positive effect on farmers' willingness to continue the CF program. Jan \& Akram (2018) state that age variables negatively affect the adoption of a program, the older the farmers the more they do not want to accept and implement new innovations as they have been comfortable with the routine performed. In this research, age had a positive and significant effect on farmers' willingness to continue the CF program. This is because members of the Barokah Farmer Group liked and learned new things even though their age was included in the category of unproductive age. Farmers with productive age found it easier and faster to accept innovation. They also had a mindset that could be improved to be wiser in facing innovations that were introduced and applied. It would ease the implementation of the CF program conducted in groups (Wongkar et al., 2016; Perwitasari et al., 2018). Barokah Farmer Group members were included in the productive age category, meaning that they were able to work with physical strength as an effort to meet the needs. 
They could develop quickly in adopting new innovations in accordance with technological advancements and helped each other in the process of technology adoption. With all CF implementation activities carried out together, they could help and direct farmers to those who were no longer productive because they still wanted to learn. So the age significantly influenced farmers' willingness to continue the program $\mathrm{CF}$ although the proportion of productive and unproductive age were the same.

Education had a positive effect on farmers' willingness to continue the $\mathrm{CF}$ program. Formal education affected on the mindset and absorptive capacity of farmers and the dissemination of information (Susanti et al., 2016). It is because with education that had been obtained by members of the Barokah Farmer Group, it is easier to receive information about the advantages and disadvantages of implementing a CF program. Then the information was used to make decisions in continuing the $\mathrm{CF}$ program. This means that even though the average education of members were only 7 years, nevertheless they had received formal education so that they would try to make the best of their ability to follow the development of existing technology, especially in terms of implementing the CF program. The majority activities of CF program majority involved agricultural machinery. Meanwhile, the machines were rarely used by farmers in their daily activities. For farmers having formal education background, it is easy for them to learn operating the machine assisted by CF management.

The number of family dependents had no significant effect on farmers' willingness to continue the program $\mathrm{CF}$ because the decision to continue the $\mathrm{CF}$ program taken only by members of the Barokah Farmer Group as the head of the family. They only supported any decision taken by the head of the family and assist in the process of farming activities. The CF land area also had no significant effect on the farmers' willingness to continue the CF program. CF land area that were combined into one block in order that tractors, transplanter and combine harvester can be used effectively and efficiently. Farming performance with CF Program is seen from the productivity of rice after the implementation of program CF had no significant effect. Trust to stakeholders also had no significant effect on farmers' willingness to continue the CF program.

\section{CONCLUSION AND SUGGESTION}

Farmers' willingness to continue $\mathrm{CF}$ program is in the category of a high score. Attitudes towards private ownership, interaction among members of farmer group, support from family 
members, age and education affect positively and significantly on farmers' willingness to continue CF program. Cohesiveness among Barokah Farmer Group members should be improved by making a regular schedule of rice cultivation activities done together by its members. Interaction among farmer group members also needs to be improved by adding a scheduled meeting or a group meeting. The awareness of farmers and their family members about the CF program and its sustainability also needs to be improved by conducting regular socialization and a more thorough discussion. Age becomes a potential factor for the majority of farmers who were still in the productive age category. It is easy to encourage these farmers to do something, for example, share new information to the others. Education can be improved by training and coaching as well as routine socialization carried out by stakeholders so that the mindset of farmers becomes more open. Also, it is essential to facilitate the adaptation process of the CF Program.

\section{REFERENCES}

Allahyari, M. S., Damalas, C. A., Daghighi Masouleh, Z., \& Ghorbani, M. (2018). Land Consolidation Success in Paddy Fields of Northern Iran: An Assessment Based on Farmers' Satisfaction.
Land Use Policy, 73(January), 95101. https://doi.org/10.1016/j. landusepol.2018.01.035

Anwar, M. I. (2015). Skala Pengukuran Variabel-Variabel Penelitian. Bandung: ALFABETA.

Armstrong, A., \& Stedman, R. C. (2012). Landowner Willingness to Implement Riparian Buffers in A Transitioning Watershed. Landscape and Urban Planning, 105(3), 211-220. https://doi.org/10.1016/j. landurbplan.2011.12.011

Azwar, S. (1999). Dasar-Dasar Psikometrik. Yogyakarta: Pustaka Pelajar.

Bose, A. K. (2013). Issues of Landlessness, Contract and Corporate Farming. Journal of Land and Rural Studies, 1(1), 25-39. https://doi. org/10.1177/2321024913483037

Brown, J. (2006). Social Psychology. Washington-DC: McGraw-Hill Humanities/Social Sciences/ Languages.

Fischer, S., \& Wollni, M. (2018). The Role of Farmers' Trust, Risk and Time Preferences for Contract Choices: Experimental Evidence from the Ghanaian Pineapple Sector. Food 
Policy, 81(October 2017), 6781. https://doi.org/10.1016/j. foodpol.2018.10.005

Hiironen, J., \& Riekkinen, K. (2016). Agricultural Impacts and Profitability of Land Consolidations. Land Use Policy, 55, 309-317. https://doi.org/10.1016/j. landusepol.2016.04.018

Jan, I., \& Akram, W. (2018). Willingness of Rural Communities to Adopt Biogas Systems in Pakistan : Critical Factors and Policy Implications. Renewable and Sustainable Energy Reviews, 81(June 2017), 31783185. https://doi.org/10.1016/j. rser.2017.03.141

Kasijadi, F., Suryadi, F., \& Suwono. (2003). Pemberdayaan Petani Lahan Sawah Melalui Pengembangan Kelompok Tani dalam Perspektif Corporate Farming di Jawa Timur. Jurnal Pengkajian Dan Pengembangan Teknologi Pertanian, 6(2), 117130.

Musthofa, I., \& Kurnia, G. (2018). Prospek Penerapan Sistem Corporate Farming. AGRISEP, 16(1), 1122. https://doi.org/10.31186/ jagrisep.17.1.11-22

Perwitasari, H., Irham, I., Hardyatuti, S., \& Hartono, S. (2018). Farmers'
Willingness to Continue Landscape Integrated Pest Management Programs in Central Java and East Java Indonesia. 172(FANRes), 15-19. https://doi.org/10.2991/ fanres-18.2018.4

Pickford, H. C., Joy, G., \& Roll, K. (2016). Psychological Ownership Effects and Applications. In Mutuality in Business (p. 25). Oxford: Saïd Business School and University of Oxford.

Pierce, J. L. ., Kostova, T., \& Dirks, K. T. (2001). Toward a Theory of Psychological Ownership in Organizations. The Academy of Management Review, 26(2), 298310. Retrieved from https://www. jstor.org/stable/259124

Sardianou, E., \& Genoudi, P. (2013).Which factors Affect the Willingness of Consumers to Adopt Renewable Energies? Renewable Energy, 57, 1-4. https://doi.org/10.1016/j. renene.2013.01.031

Simanjuntak, O. V., Subejo, S., \& Witjaksono, R. (2016). Partisipasi Petani dalam Program Gerakan Penerapan Pengelolaan Tanaman Terpadu Padi di Kecamatan Kalasan Kabupaten Sleman. Agro Ekonomi, 27(1), 20. https://doi. 
org/10.22146/jae.22693

Susanti, D., Listiana, N. H., \& Widayat, T. (2016). Pengaruh Umur Petani, Tingkat Pendidikaan dan Luas Lahan terhadap Hasil Produksi Tanaman Sembung. Jurnal Tumbuhan ObatIndonesia, 9(2), 7582. Retrieved from http://ejournal. litbang.depkes.go.id/index.php/ toi/article/view/7848/5318

Swain, P. K., Kumar, C., \& Kumar, C. P. R. (2012). Corporate Farming vis-avis Contract Farming in India : A Critical Perspective. International Journal of Management and Social Sciences Research (IJMSSR), 1(3),
60-70.

Wahyuni, S., \& Pranadji, T. (2015). Konsep, Implementasi, dan Faktor Penentu Keberhasilan Program Konsolidasi Usahatani. Jurnal Manajemen \& Agribisnis, 12(1), 14-26. https://doi.org/10.17358/ JMA.12.1.14

Wongkar, D. K. R., Wangke, W. M., Loho, A. E., \& Tarore, M. L. G. (2016). Hubungan Faktor-Faktor Sosial Ekonomi Petani dan Tingkat Adopsi Inovasi Budidaya Padi di Desa Kembang Mertha, Kecamatan Dumoga Timur, Kabupaten Bolaang Mongondow. Agri-Sosioekonomi, 12(2), 15-32. 